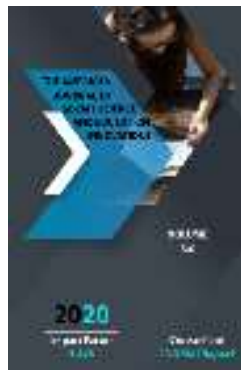

\title{
Ethnoecological Culture Of The Uzbek People Today And Pedagogical Aspects Of Its Formation In Students
}

\author{
Nigora Pulatova \\ Independent Researcher At The Department Of Civil Society, Fergana State University, \\ Uzbekistan
}

\begin{abstract}
Journal Website: http://usajournalshub.c om/index,php/tajssei

Copyright: Original content from this work may be used under the terms of the creative commons attributes 4.0 licence.
\end{abstract}

\section{ABSTRACT}

The peculiarities of the ethno-ecological culture of the Uzbek people today, the forms of its manifestation, the pedagogical system of its formation in young people, especially students of higher education, the socio-pedagogical necessity are examined in this article. Moreover, the article also examines the compatibility of the creation of an educational environment in the higher education system aimed at the formation of ethno-ecological culture in students with the socio-economic requirements of society and the main approaches to the formation of ethno-ecological culture of students.

\section{KEYWORDS}

Education, higher education, student, nature, ecology, culture, ecological consciousness, ecological ethics, ethnos, ethnoecology, ethnoecological culture.

\section{INTRODUCTION}

Overcoming the problem of economic, social, demographic, spiritual and environmental crisis in the world in the fields of human activity is arisen as a problem of modern civilization. The rapidly evolving world labor market and high-tech development in the field of social development introduces the duty of raising students' environmental competencies, environmental culture to a higher level, the delivery of competent, armed with modern ethno-ecological knowledge. Many countries' experience in the world reveals that education system is the best executor in the process of tackling national problems. The environmental 
risks could be reduced through the education of children, adults, the country in which they live and the world at large. [1]

In today's world, where the process of modern globalization is accelerating rapidly, the issue of living in an environmentally safe space for human health is becoming an increasingly pressing issue. Today, it is essential to form a national strategy to protect the country, society and the individual from global, regional and national environmental threats posed by globalization, and to improve the protection of the environment and people's health to address these threats. [2]

The basis of national goals and objectives in the field of sustainable development until 2030 in the republic is to help a healthy lifestyle and promote the well-being of people of all ages, the preservation and rational use of biodiversity and ecosystems, environmental sustainability[3].

The current condition of society and nature leads to catastrophic events as a result of the deterioration of the quality of living conditions in the external environment, the loss of biological diversity and stability, the chaotic impact on the biosphere. The acceleration of scientific and technological progress, the imperfection of production technology, consumer traditions in relation to nature - all this is the main reason for the escalating of the contradictions between society and nature.

\section{MATERIALS AND METHODS}

The concepts of ethnoecological literacy and culture were introduced and formed in the Eastern world 3,000 years ago. The great work "Avesto" is the earliest document on nature protection and conservation. [4] There are several instructions about saving nature in the works of great Scientists of east world who are Abu Nasr Farobi, Abu Rayhon Beruni, Zakhiriddin Mukhammad Bobur.[5] The actions of A.Tukhtaev [6], E.O.Turdikulov [7], B.Ziyomuhammedov [8], A.Nigmatov [9], T.Ergashev, A.Ergashev [10] , Sh.T.Otaboev,
R.U.Beknazarov, Yu.G.Mahmudov, C.H.Fayzulina, D.Yormatova in the Ethnology's field are commendable on the issue that theoretical bases of ecology and environmental protection in the Republic of Uzbekistan. N. Bozorova and A. Malikova, scientists of Uzbekistan, have produced the methodological basis of the dutiness of raising ethno-ecological literacy of students in higher education and their application.

In the early fifty's of the twentieth century, the science of ethnographic geography was formed about the geographical location of peoples and the characteristics of their expantion. Ethnogeography has also functioned as a foundation for a particular branch of science - ethnic ecology. Thus, the term "ethnic ecology" was introduced into scientific circulation in the early eighty's [11]. The formation of the science of ethnic ecology was significantly influenced by the concept of "Cultural Ecology" [12] by the American anthropologist Julian Steward, as well as ethnoecological schools and trends that influenced significantly in the United States

In the development of the science of ethnic ecology, V.P. Alekseev's research played an important role. In his research, the author proved the concept of "anthropogeocenos". According to him, the anthropogeocenosis was interpreted as an economic community and a territorial unit developed by him [13].

\section{ANALYSIS AND RESULTS}

The world countries' the ethno-ecological stability is determined annually according two main criteria: ecological health and the survival of ecosystems based on 24 indicators. A properly analysis of ethno-ecological developments and processes will help in the conduct of world politics. In this regard, the EPI - (International Ecological Indicators Level) [14] has been established, in that 180 countries are regularly assessed. Among 180 countries, Uzbekistan ranks 118th, and a comparative analysis of the rating scores reveals it scored 
50.67 points. Being inferior level of production and technology, the slow development of measures to make sure environmental sustainability indicate the necessity for perfect development of environmental literacy and competence in our country. The ecological purity of Uzbekistan in 2018 was assessed according to the result of the world analysis as follows: 136th place in terms of environmental efficiency, compared to the previous 158th place; The presence of forests in only 130 out of 180 countries in terms of forests and their protection, and the fact that Uzbekistan ranks 12th, testifies to the invaluable nature of our country. Especially, registration this point is changing dramatically to positive side gives information about developing of nature protection system.

The concept of development of ecological education of the Republic of Uzbekistan in order to implement the tasks set out in the action strategy for the five priority areas of development of the Republic of Uzbekistan in 2017-2021, the formation and development of ecological consciousness and culture of the younger generation through the education system [15] and the establishment of the Ecological Party of Uzbekistan on the basis of the Ecological Movement of Uzbekistan will contribute to the reasonable and lawful development of environmental protection and sustainable development.

Perfect ecological thinking and the ability to think wisely about nature in the human-naturesociety system, only ecological competence can save the future biosphere. The new appearance of education consists of competent and qualified specialists who are able to see and analyze the problems of the social and environmental levels as a complete, to think systematically and creatively. Demanding on students to learn scientific of competent structure, the definition of its pedagogical model of environmental training is need.
Ethnologic culture, initially, saving the nature by realizing nature rules without damaging to environment.

The development of ethno-ecological culture is associated with the dissemination of information to the population on the development of ecological consciousness of the people, the strengthening of propaganda.

In order to form the concept of ethnoecological culture in the media, the population should learn about nature, land, subsoil resources, water, flora and fauna, natural resources, conservation of natural geno-fund, living environment, rational use of nature, national values and traditions, customs as well as information on the main directions of state policy in the field of nature protection.

Uzbekistan has gathered some experience in upcoming environmental problems and preventing their negative consequences during the years of independence. But, in this area, task's scale and scope require the joint efforts of government agencies, public associations and citizens to address the problem of improving the ecological environment in our country.

Currently, wide community attention should be paid to protecting nature and duty is one of the most vital issues. According to this, improving the culture of environmental protection in people should be the focus of public administration and the activities of spiritual and educational institutions.

The ecology is being taught in each levels of education in Uzbekistan. This subject studies the living conditions of living organisms and their complex communications with the environment in which they live and the laws that arise on this basis. In the development of ethno-ecological mind, it is important to explain to the general public that the unity of nature, the interdependence of all events and processes, changes in attitudes to the environment, the doctrine of the biosphere, the evolution of the organic world, the unity of 
chemical, biological and physical processes. Without any doubt, in this issue ecological culture has great position, pupils of schools and university students are learning the aspects about saving balance of ecosystem, protecting and using natural resources, the importance of ecological balance on the life of living organisms, the reasons of appearing ecological problems.

Although the concept of ethnoecological culture has existed to some extent in the way of life of all peoples since ancient times, it was first proposed by Western scholars as a particular direction in science in the second half of the twentieth century [16].

Advances in science and technology, the development of knowledge about environmental protection, and the escalation between nature and society have led to the separation of ecology from a small part of the biological sciences and its formation as a separate science. Ecology has ed into all branches of the natural sciences and covered the economic, political, cultural and social spheres, that are essential aspects of society.

On the basis of this process, which covers all spheres and directions of nature and society, that is "Ecologization", the science of ecology of global significance was formed that today has a complex system. Today ecology includes about 70 sets of doctrines and ideas in the "Nature-Society System", that are human ecology, economic ecology, engineering ecology, agroecology, chemical ecology, legal ecology and others [17].

So, this problem has several important social directions, such as geographical, ethnological, legal. Only when the accumulated experiences are generalized in these areas, an attitude of mind towards the environment will be formed.

The traditions of our ancestors in relation to nature, flora and fauna, developed traditions and folk ecological culture from ancient times, combining experiences. As an integral and most important part of folk culture, national values related to environmental protection have matured.

The material and spiritual culture of a nation develops, history also does it. The living conditions, ceremonies and traditions of each nation were formed during the historical development of that nation. In particular, one of the unique historical and ethnographic regions of Uzbekistan, the Fergana Valley is characterized by the fact that the economic traditions of the Uzbeks have retained their national identity despite various economic and political changes over the centuries.

The development of a culture of wisely usage of natural resources in this area is not a simple process, but it is a system of activities related to the practical initiative of the public, ideological and political consciousness, the level of education.

Ethno-ecological culture is concerned to all sides of life as a multilateral and complex event. In the line any kind of field is impossible to develop without ethno-ecology. This situation shows assessing socially feature of development. So, adjoining to concrete-history to ecological culture can make it explain right.

The duty of ordering ethno-ecological culture is appeared clearly on ceremony, traditions. Of course, any cultural norm can emerge as a factor regulating a person's activities only if it becomes an inner belief. Therefore, we find out to what extent the population has mastered the norms of ecological culture by looking at how they behave in different conditions. Thus, one of the important features of culture is the activity of people, the regulation of communication, the formation of lifestyles, the subordination of social relations to certain norms.

The formation of a new outlook on life on our planet with a deep understanding of ethnoecological culture is a long process. In this mean, the development of theoretical methodology of the problem of ecological culture plays an important role. 


\section{CONCLUSION}

In conclusion, the following should be recognized as an essential task in the development of a new theoretical methodology for the scientific analysis of the history of modern ethno-ecological culture:

- To develop of studying ethno-ecological culture methodology;

- To study the historical stages of the genesis and formation of ethno-ecological culture and develop theoretical, practical and methodological recommendations for its development;

- To determine the functional significance of the Uzbek ecological culture in the development of society;

- Demonstration of inheritance relations and methods of its development in the development of ethno-ecological cultural heritage.

It would be expedient if ecologists, geographers, ethnologists, sociologists and lawyers came together and developed a code of environmental ethics within the framework of the mentality of the people. In addition, the development of folk ethno-ecological culture can be achieved through the coverage of theoretical knowledge in these areas in the media on the basis of a special program. The plant and animal world is a priceless treasure that not only we, but also future generations should use.

In conclusion, in order to raise the modern ethno-ecological culture, there is a necessity to further strengthen the advocacy work of ecologists, geographers, ethnologists, sociologists and lawyers, to raise the modern ecological culture of the people to a new level. So, given the importance of this problem for the social life of the republic, it is necessary to pay serious attention to its scientific and practical aspects.

Firstly, forming the ethno-ecological culture of students is concerning to rational field and emotionally field. Moral-practical absorbing of one of the part of culture also form.

Secondly, the goal of teaching can be considered achieved only if the student has not only acquired the set of knowledge set out in the curriculum, but also mastered the need to supplement them independently, as well as the skills of independent work.

Third, the inclusion of environmental issues in the topic of student research work is extremely important in shaping the ethno-ecological culture of the specialist. In addition, all universities in the country now have all the conditions to coordinate the work on the formation and development of ethnoecological culture of the student as a person, to open ethno-ecological centers under the guidance of leading teachers and active students.

Fourth, the process of formation and development of ethno-ecological culture in higher education institutions is not over. The graduate of the university will acquire a solid foundation in general and private environmental knowledge, the basic principles of ecology, will have the skills to work independently in this area.

\section{REFERENCES}

1. Tursunov X. Basics of ecology and nature protection. - T .: Uzbekistan, 1997. - $51 \mathrm{p}$.

2. X.Azzamov. environmental problems are a concern for humanity. (2013) 30.04.2015 ziyouz.uz

3. Resolution of the Cabinet of Ministers of the Republic of Uzbekistan on measures to implement national goals and objectives in the field of sustainable development until 2030, 2018.20.10, No. 814.

4. H.Khomidov, "Fayzlari" Avesto ", Tashkent-2001, 15 pages

5. Abu Nasr Farobi, "City of noble people", $T$ .: 2004. - 16ob, 26-b; "El desa Navoiini", folk tales, T .: Cholpon, 1991. - 16ob, 154-b; 
6. Tukhtaev A., Khamidov A. Basics of ecology and nature protection. - Tashkent: Teacher, 1994. $-159 \mathrm{p}$.

7. Turdiqulov E.O. The environment and man. - T .: Bioekosan, 1996. - 28 p.

8. Ziyomuhammedov B. Ecology and spirituality. - T .: Mehnat, 1997. - 104 p.

9. Nig'matov A. Man and soil. - T .: G'.G'ulom, 2002. - 47 p.

10. Ergashev A. General ecology. - T .: Uzbekistan, 2003. - 463 p.

11. Kozlov V. I. Ethnic demography. - M., 1977. p. 42 .; Kozlov V. I. Mnogoaspektnost etnicheskoy ekologii. Ethnoecological research. Sbornik statey k 80-letiyu so dnya rozhdeniya V.I. Kozlova. - M .: Staryy Sad, 2004. - p. 8-9.

12. Sadoxin A. P. Ethnology. - M .: Gardariki, 2008. - p. 76-78.

13. Alekseev V. P. Anthropogeocenosis dryness, typology of dynamics // Nature. 1975. № 7. - p. 20 .; Alekseev V. P. Essays on human ecology. - M., 1993. - 191 p.

14. https://epi.envirocenter.yale.edu. Uzbekistan.

15. Resolution of the Cabinet of Ministers of the Republic of Uzbekistan dated 14.06.2018 "Concept of development of ecological education of the Republic of Uzbekistan" (draft normative legal act).

16. O r I o v B. C. Ecological anthropology // Annual Rev. of Anthrop. 1980. Vol. 9.Pp. 235-273

17. Ecological law. A textbook for law students of higher educational institutions. - $\mathrm{T}$.: Tashkent State Law Institute, 2001. - B. 33. 